University of Windsor

Scholarship at UWindsor

$10-2014$

\title{
Activated Cyclopropanes: A Remarkable Breadth of Recent Chemistry
}

James R. Green

University of Windsor

Victor Snieckus

Queen's University - Kingston, Ontario

Follow this and additional works at: https://scholar.uwindsor.ca/chemistrybiochemistrypub

Part of the Biochemistry, Biophysics, and Structural Biology Commons, and the Chemistry Commons

\section{Recommended Citation}

Green, James R. and Snieckus, Victor. (2014). Activated Cyclopropanes: A Remarkable Breadth of Recent Chemistry. Synlett, 25 (16), 2258-2259.

https://scholar.uwindsor.ca/chemistrybiochemistrypub/69

This Article is brought to you for free and open access by the Department of Chemistry and Biochemistry at Scholarship at UWindsor. It has been accepted for inclusion in Chemistry and Biochemistry Publications by an authorized administrator of Scholarship at UWindsor. For more information, please contact scholarship@uwindsor.ca. 


\title{
Activated Cyclopropanes: A Remarkable Breadth of Recent Chemistry
}

\author{
James R. Green* ${ }^{\mathrm{a}}$, Victor Snieckus* ${ }^{\mathrm{b}}$ \\ ${ }^{a}$ Department of Chemistry and Biochemistry, University of Windsor, Windsor, ON, N9B 3P4, Canada \\ E-mail: jgreen@uwindsor.ca \\ ${ }^{\mathrm{b}}$ Department of Chemistry, Queen's University, Kingston, ON, K7L 3N6, Canada \\ E-mail: Victor.Snieckus@chem.queensu.ca
}

Received: The date will be inserted once the manuscript is accepted.

\begin{abstract}
The reactions of cyclopropanes activated by electron withdrawing groups and electron-donating groups (DA cyclopropanes) and with alkenyl- or alkylidene substituents has been an area of recent intense research activity. This Cluster contains contributions from many of leading research groups in this area, and provides a concise introduction to the rich ring opening, ring expansion, dimerization, and cycloaddition chemistry of these compounds.
\end{abstract}

Key words: cyclopropanes, ring opening, cycloaddition, rearrangement, Lewis acids, catalysis

The interest in the chemistry of cyclopropanes is in part driven by the discussion of the nature of their C-C bonds in terms of bonding models, ${ }^{1}$ and more recently their existence in natural products; ${ }^{2}$ these have stimulated countless developments in cyclopropane ring forming reactions, ${ }^{3}$ including Simmons-Smith, dihalocarbene, ${ }^{5}$ diazoalkane cycloaddition, ${ }^{6}$ and Kulinkovich processes. ${ }^{7}$ However, much of the recent chemistry of cyclopropanes derives from their ring opening chemistry. Given the approximately 27.5 $\mathrm{kcal} / \mathrm{mol}(115 \mathrm{~kJ} / \mathrm{mol})^{8}$ strain energy, the addition of polar functional groups has resulted in a rich, accessible, and predictable reactivity for the ring system (Figure 1). In particular, the ability of electronwithdrawing group substituted cyclopropanes (1) to act as $\gamma$-carbonyl cation equivalents/homologous Michael reaction substrates (eqn 1), the ability of electron donating group substituted cyclopropanes (2) to act as homologous enolate equivalents (eqn 2), and most prominantly, the ability of DA cyclopropanes (3) to act in both modes, have resulted in wide ranging synthetic application. Although the early work of Danishefsky has no doubt served as an inspiration ${ }^{9}$ and each of these subjects has a significant history, ${ }^{10-12}$ the chemistry of these 'activated cyclopropanes' has enjoyed a renaissance in the past decade. ${ }^{13}$ The modes of activation of the cyclopropanes by nucleophiles, electrophilic species and transition metal catalysts have expanded greatly and include a wide range of cyclodimerizations, $3+2$ cycloadditions, $3+3$ cycloadditions, and ring expansion reactions. Further, it is not necessary to restrict the 'activated cyclopropane' terminology to strong donor and/or acceptor classes, as alkylidenecyclopropanes (4, Figure 2) $)^{14}$ and vinylcyclopropanes $(5)^{15}$ are being shown to experience rich ring opening, ring expansion and cycloaddition chemistry, including multicomponent and higher order cycloadditions.

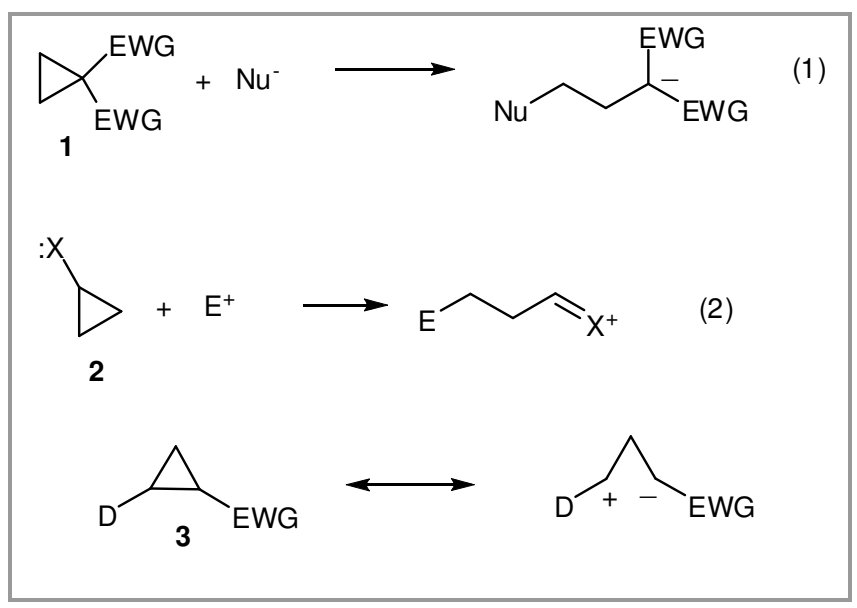

Figure 1 Acceptor, donor, and donor-acceptor substituted cyclopropanes,

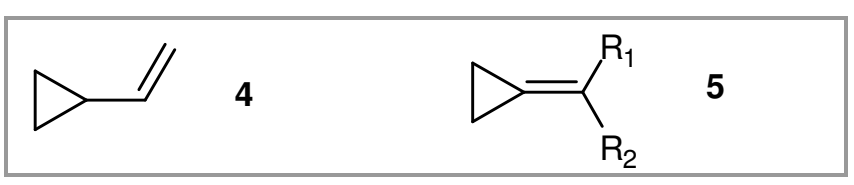

Figure 2. Alkylidene cyclopropanes and vinylcyclopropanes

It is our intention for the contributions of this Cluster to reflect the recent advances in this chemistry, from many of the leading research groups in the area. Orellana and coworkers describe a tandem homoenolate coupling/imine formation process to form quinolines from hydroxycyclopropanes and ortho- bromoanilines. The Liang group discloses lactam formation processes by way of organocatalyzed ring exapansion/alkylation reactions of keto- amide substituted cyclopropanes. The Reissig group reports the ring opening of silyl ether containing donor-acceptor cyclopropanes to nitrileand alkyne substituted esters. A Lewis acid mediated $3+2$ cyclodimerization of indole- substituted donoracceptor cyclopropanes is explored by the Budynina group. Both preparation of amido donor-acceptor substituted cyclopropanes and their 3+2 cycloadditions with enol silanes is reported by the Waser group. The Ioffe group reports the $3+3$ cycloaddition chemistry of silyl nitronates with donoracceptor cyclopropanes and subsequent ring contractions to pyrroline $\mathrm{N}$-oxides. A tandem azide ring opening/alkyne click reaction of donor- acceptor cyclopropanes is detailed by Kerr and co-workers. 
Several contributions highlight vinyl- substituted DA cyclopropane reactions. The Plietker group discloses an iron-NHC catalyzed $3+2$ cycloaddition process with enals or enones. The Kimura group contributes a palladium catalyzed, zinc mediated bis-homoaldol process of these compounds. Kurahashi and coworkers report a nickel mediated $3+2$ cycloaddition process vinyl/DA cyclopropanes with alkenes. The tandem Diels-Alder/3+2 cycloadditions of dienesubstituted DA cyclopropanes with enals or enones is reported by Wang and co-workers.

The Shi group makes two contributions to this Cluster. A carbonylative ring expansion reaction of

\section{References}

(1) de Meijere, A. Angew. Chem. Int. Ed. Engl. 1979, 18, 809.

(2) (a) Donaldson, W. A. Tetrahedron 2000, 56, 8589. (b) Faust, R. Angew. Chem. Int. Ed. 2001, 40, 2251. (c) Chen, D. Y.-K.; Pouwer, R. H.; Richard, J.-A. Chem. Soc. Rev. 2012, 41, 4631.

(3) (a) Lebel, H.; Marcoux, J.-F.; Molinaro, C.; Charette, A. B. Chem. Rev. 2003, 103, 977. (b) Pellissier, H. Tetrahedron 2008, 64, 7041 .

(4) (a) Charette, A. B.; Beauchemin, A. Org. React. 2001, 58 , 1. (b) Concellón, J. M.; Rodríguez-Solla, H.; Concellón, C.; del Amo, V. Chem. Soc. Rev. 2010, 39, 4130.

(5) Fedoryński, M. Chem. Rev. 2003, 103, 1099.

(6) (a) Doyle, M. P. J. Org. Chem. 2006, 71, 9253. (b) Wee, A. G. Curr. Org. Synth. 2006, 3, 499.

(7) Cha, J. K.; Kulinkovich, O. G. Org. React. 2012, 77, 1.

(8) Wiberg, K. B. Angew. Chem. Int. Ed. Engl. 1986, 25, 312.

(9) For early work on acceptor substituted cyclopropanes, see: Danishefksy, S. Acc. Chem. Res. 1979, 12, 66.

(10) For early work on donor substituted cyclopropanes, see: (a) Saluan, J. R. Y. Top. Curr. Chem. 1988, 144, 1. (b) Kuwajima, I.; Nakamura, E. Top. Curr. Chem. 1990, 155, 1. (c) Kulinkovich, O. G. Chem. Rev. 2003, 103, 1071.

(11) For early work on donor-acceptor cyclopropanes, see: Reissig, H.-U.; Zimmer, R. Chem. Rev. 2003, 103, 1151.

(12) For reviews on multiple facets of earlier cyclopropane chemistry, see: (a) Wong, H. N. C.; Hon, M. Y.; Tse, C. W.; Yip, Y. C.; Tanko, J.; Hudlicky, T. Chem. Rev. 1989, 89, 165. (b) Rubin, M.; Rubina, M.; Gevorgyan, V. Chem. Rev. 2007, 107, 3117. (c) Tang, P.; Gin, Y. Synthesis 2012, 44, 2969.

(13) (a) Yu, M.; Pagenkopf, B. L. Tetrahedron 2005, 61, 321. (b) Carson, C. A.; Kerr, M. A. Chem. Soc. Rev. 2009, 38, 2969. (c) Campbell, M. J.; Johnson, J. S.; Parson, A. T.; Pohlhaus, P. D.; Sanders, S. D. J. Org. Chem. 2010, 75, 6317. (d) Lebold, T. P.; Kerr, M. A. Pure Appl. Chem. 2010, 82, 1797. (e) Mel'nikov, M. Ya.; Budynina, E. M.; Ivanova, O. A.; Trushkov, I. V. Mendeleev Commun. 2011, 21, 293. (f) Tang, P.; Qin, Y. Synthesis 2012, 44, 2311. (g) Wang, Z. Synlett, 2012, 23, 2311. (h) Schneider, T. F.; Kaschel, J.; Werz, D. B. Angew. Chem. Int. Ed. 2014, 53, 5504. (i) de Nanteuil, F.; De Simone, F.; Frei, R.; Benfatti, F.; Serrano, E.; Waser, J. Chem. Commun. 2014, 50, 10912. vinyl/alkynyl substituted cyclopropanes to give tricyclic 5,5,6- systems is described. In addition, this group details the Lewis acid catalyzed ring opening of alkylidenecyclopropanes by intramolecular traizole attack.

It is our belief that these contributions, taken together, give a good sense of current progress and high level of activity in studies of the chemistry of cyclopropanes. We are grateful to each of the groups for their contribution to this Cluster.

(14) (a) Masarwa, A.; Marek, I. Chem.- Eur. J. 2010, 16, 9712. (b) Pellissier, H. Tetrahedron 2010, 66, 8341. (c) Zhang, D.-H.; Tang, X.-Y.; Shi, M. Acc. Chem. Res. 2014, 913. (d) Brandi, A.; Cicchi, S.; Cordero, F. M.; Goti, A. Chem. Rev. 2014, 114, 7317. (e) Mack, D. J.; Njardson, J. T. ACS Catal. 2013, 3, 272.

(15) Jiao, L.; Yu, Z.-X. J. Org. Chem. 2013, 78, 6842. 
